\title{
Substrate roughness affects stream benthic algal diversity, assemblage composition, and nestedness
}

\author{
Author(s): Fabiana Schneck and Albano SchwarzboldAdriano S. Melo \\ Source: Journal of the North American Benthological Society, 30(4):1049-1056. \\ Published By: The Society for Freshwater Science \\ DOI: http://dx.doi.org/10.1899/11-044.1 \\ URL: http://www.bioone.org/doi/full/10.1899/11-044.1
}

BioOne (www.bioone.org) is a nonprofit, online aggregation of core research in the biological, ecological, and environmental sciences. BioOne provides a sustainable online platform for over 170 journals and books published by nonprofit societies, associations, museums, institutions, and presses.

Your use of this PDF, the BioOne Web site, and all posted and associated content indicates your acceptance of BioOne's Terms of Use, available at www.bioone.org/page/terms_of_use.

Usage of BioOne content is strictly limited to personal, educational, and non-commercial use. Commercial inquiries or rights and permissions requests should be directed to the individual publisher as copyright holder. 


\title{
Substrate roughness affects stream benthic algal diversity, assemblage composition, and nestedness
}

\author{
Fabiana Schneck ${ }^{1}$ AND Albano Schwarzbold ${ }^{2}$ \\ Programa de Pós-Graduação em Ecologia, Instituto de Biociências, Universidade Federal do Rio Grande do \\ Sul, CP 15007, CEP 91501-970, Porto Alegre, RS, Brazil
}

Adriano S. Melo ${ }^{3}$

Departamento de Ecologia, ICB, Universidade Federal de Goiás, CP 131, CEP 74001-970, Goiânia, GO, Brazil

\begin{abstract}
Heterogeneity generated by irregularities on the surface of streambed substrates is an important determinant of local species diversity of algae. However, few investigators have examined the effects of substrate roughness on the composition of algal growth forms and on patterns of species distribution. We examined the influence of substrate roughness on stream benthic algal assemblages through a field experiment with 2 treatments (smooth and rough artificial substrates for algal colonization). We assessed whether species richness, density, and assemblage composition of benthic algae (all taxa and those in 5 growth-form groups) differed between treatments and whether differences in species composition between substrates were the result of species turnover or nestedness. We also used a data subsampling procedure to investigate the effect of differences in species richness between treatments. Total species richness was higher on rough than on smooth substrates, but density did not differ between treatments. Species richness, density, and composition of the adnate/prostrate growth form did not differ between treatments. The erect/stalked growth form had higher species richness on rough substrates, but did not differ in density between treatments. All other growth forms (filamentous, motile, and metaphyton) had higher species richness and density on rough substrates and differed in species composition between substrates. The results of the subsampling analysis indicated that assemblage composition was affected by differences in species richness and by changes in species composition (i.e., turnover). Species distribution had a nested pattern, in which the assemblages on smooth substrates were a subgroup of the species occurring on rough substrates. We suggest that the differences in assemblage composition between smooth and rough substrates resulted from variability in species' capabilities to colonize substrates with or without crevices. This variability resulted in both nestedness and turnover.
\end{abstract}

Key words: algal growth form, nested habitats, species turnover, distribution, periphyton.

Habitat heterogeneity is a major driver of diversity in lotic ecosystems and acts at different spatial scales, such as reaches, pools and riffles, and streambed substrates (Murdock and Dodds 2007). The heterogeneity generated by irregularities on the surface of streambed substrates (e.g., crevices, projections) is an important determinant of local species diversity of algae (Bergey 1999, 2005), rotifers (Vieira et al. 2007), and macroinvertebrates (Downes et al. 2000, Hutchens et al. 2004, Taniguchi and Tokeshi 2004). In 7 of 11 studies of the effects of surface texture on stream

\footnotetext{
${ }^{1}$ E-mail addresses: fabiana.schneck@gmail.com

2 aschwarzbold@terra.com.br

3 asm.adrimelo@gmail.com
}

invertebrate richness, species richness was significantly higher on more complex surfaces (Palmer et al. 2010). These differences in species diversity can be attributed to several mechanisms. For example, finescale substrate texture can affect retention of food resources and sediment and can provide refuges from high-discharge events, abrasion, desiccation, and predators (Dudley and D'Antonio 1991, Taniguchi and Takeshi 2004, Bergey 2005).

Rough substrates influence algal colonization (Bergey et al. 2010) and protect algae from grazers and disturbances better than smooth substrates do (Dudley and D'Antonio 1991). Algal biomass increases with substrate roughness and crevice availability (Bergey 2005, Murdock and Dodds 2007), and crevice 
size influences algal size distribution and species composition (Bergey 1999). However, the effects of substrate roughness on algal growth-form composition or patterns of species distribution are not well understood.

The positive effect of substrate roughness on species diversity (Bergey 1999, Vieira et al. 2007) led us to hypothesize that rough substrates might allow coexistence of species able to colonize smooth substrates with species that need crevices for their establishment. Thus, a nested pattern of species distribution might be expected to occur between substrates with different degrees of roughness if species that are more susceptible to grazers and disturbance are selectively removed from smooth substrates. However, nestedness is not the only pattern that could emerge. Algal assemblages on smooth and rough substrates also could vary because of species turnover between substrate types. Nestedness and patterns caused by turnover are not mutually exclusive (Lennon et al. 2001, Baselga 2010).

We conducted a field experiment to study the influence of substrate roughness on species richness, density, growth-form composition, and species distribution of stream benthic algae. We tested whether species richness and density were higher on rough than on smooth substrates and whether assemblage composition (all taxa and 5 growth-form groups) differed between smooth and rough substrates. We also assessed whether differences in species composition between substrates were the result of species turnover or nestedness.

\section{Methods}

\section{Study area}

We conducted our experiment in Marco Stream (lat $28^{\circ} 36^{\prime} \mathrm{S}$, long $49^{\circ} 51^{\prime} \mathrm{W}$ ) in the state of Rio Grande do Sul, southern Brazil. The study site is a $4^{\text {th }}$-order stream at $\sim 1100 \mathrm{~m}$ asl. The stream drains a catchment with low human impact and has clear, oligotrophic (Buckup et al. 2007), well oxygenated water $(10 \mathrm{mg} / \mathrm{L})$, a $\mathrm{pH}$ of $\sim 6.6$, low conductivity $(22 \mu \mathrm{S} / \mathrm{cm})$, and a mean current velocity of $26 \mathrm{~cm} / \mathrm{s}$. The stream bed is composed of basaltic stones, boulders, and bedrock. Stream width varies from 2 to $5 \mathrm{~m}$, and depth varies from 0.2 to $0.4 \mathrm{~m}$ in the study reaches.

\section{Experimental design}

We conducted the experiment from May through August 2009 (austral autumn and winter). We designed a 1-factor field experiment with 2 levels: smooth substrate and rough substrate. During the experiment, we took samples on 6 occasions (every $15 \mathrm{~d}$ ) in 11 stream reaches (66 blocks). We sampled 2 artificial substrates of each type per block to yield 264 sampling units ( 2 sampling units $\times 2$ substrate types $\times 66$ blocks $=264)$. Each pair of sampling units collected under the same conditions was pooled for analysis and constituted 1 experimental unit $(n=$ 132).

We used acrylic substrates $(5 \times 5 \mathrm{~cm})$ for algal colonization. The surfaces of the acrylic substrates were either smooth or had longitudinal crevices (substrate treatments). All rough substrates had the same number of crevices (9), and all crevices had the same width $(1 \mathrm{~mm})$ and depth $(1 \mathrm{~mm})$. We glued substrates on $50 \times 50 \times 8$-cm flat paving stones. We placed 1 stone in each of the 11 stream reaches and aligned the substrate crevices in a cross-stream direction. Each stone supported all substrates needed for the entire experiment to minimize variation of physical variables, such as current velocity and water depth, between treatments. We placed substrates on the stream bed for benthic algal colonization $45 \mathrm{~d}$ before the start of the experiment. Growth was evident on all substrates on day 45. No spates occurred during the period of the experiment.

\section{Sampling and laboratory analyses}

We brushed substrates with a toothbrush to remove periphyton, and preserved the samples with $4 \%$ formaldehyde. We determined benthic algal composition and cell density by counting 500 cells from each experimental unit with an inverted microscope at $400 \times$ magnification. We cleaned additional subsamples with acid, mounted them on glass slides using Naphrax ${ }^{\mathrm{TM}}$, and examined them at $1000 \times$ through a light microscope (Lowe and LaLiberte 2007) to identify diatom species.

We classified algae into 5 growth-form groups: 1) adnate or prostrate (species of the genera Achnanthes, Achnanthidium, Cocconeis, Epithemia, Lemnicola, and Psammothidium), 2) erect or with mucilage stalks (species of Cymbella, Encyonema, Eunotia, Fragilaria, Gomphonema, Meridion, Synedra, and Ulnaria), 3) motile algae (species of Frustulia, Hantzschia, Luticola, Navicula, Neidium, Nitzschia, Pinnularia, Stauroneis, Surirella, and Tryblionella), 4) filamentous (species of Aphanochaete, Bulbochaete, Heteroleibleinia, Oedogonium, Spirulina, Stigeoclonium, Tolypothrix, an unidentified filamentous green alga, an unidentified filamentous desmid, and an unidentified filamentous cyanobacterium), and 5) metaphyton, i.e., species without a fixation structure (species of Chlorella, Closterium, Cosmarium, Desmodesmus, Euastrum, Merismopedia, 
Pleurotaenium, Scenedesmus, Staurastrum, Staurodesmus, Synechocystis, and unidentified Chlorococcales). The classification was based on Lowe et al. (1986), Round et al. (1990), Biggs et al. (1998), Burliga et al. (2004), Passy (2007), Bixby et al. (2009), and Lange et al. (2011).

\section{Data analyses}

We assessed the effect of substrate roughness on species richness and density of the entire assemblage and of each growth-form group with paired $t$-tests and adjusted $\alpha$ values by the number of tests performed (Bonferroni correction; $\alpha^{\prime}=0.004$ ). We used ordination diagrams resulting from 2 Principal Coordinates Analyses (PCoA) of qualitative (presence/absence; Sørensen dissimilarity index) and quantitative ( $\log [$ density +1 ]; Bray-Curtis dissimilarity index) data (Legendre and Legendre 1998) to explore differences in assemblage composition and structure between smooth and rough substrates.

We conducted 2 distance-based multivariate analyses of variance (db-MANOVA; Anderson 2001) to test for differences in assemblage composition (measured with qualitative and quantitative data) between substrate types. We also used db-MANOVAs to test for differences in composition of each algal growthform group between substrate types. We ran 9999 permutations stratified within blocks for each dbMANOVA and corrected $\alpha$ values by the number of tests performed $\left(\alpha^{\prime}=0.004\right)$. In addition, we identified species associated with each type of substrate with Indicator Species Analysis (Dufrêne and Legendre 1997).

Species richness differed between substrate types (see Results). Differences in richness can cause distortions when assessing resemblance (Dargie 1986), so we used a subsampling procedure to investigate the effect of differences in species richness among experimental units on the PCoA ordination and db-MANOVA (qualitative data only). We removed the effects of species richness by reducing the number of species in the richest treatment (per block) to the same number found in the poorest treatment. The procedure consisted of: 1) random subsampling of the richest experimental unit of each of the 66 pairs of treatments (i.e., blocks) to yield the same number of species as the poorest experimental unit of the pair (i.e., equalizing the number of species between treatments), 2) calculation of a dissimilarity matrix for the new subsampled data set (Sørensen index), and 3) ordination of subsamples using PCoA and calculation of a dbMANOVA (9999 permutations stratified within blocks). Steps 1 to 3 were repeated 100 times. We used
Procrustean analysis to compare the ordination of the original data set with each of the 100 ordinations of subsampled data sets and plotted the mean values of the Procrustean scores of the subsamples in an ordination diagram to obtain a synthetic PCoA representation. We obtained the mean value of the statistics ( $F$ and $p$ ) generated by the db-MANOVA conducted for each of the 100 subsampled data sets. A similar subsampling procedure was used by Ferro and Melo (2011) to assess the robustness of PCoA results for localities differing in tiger-moth species richness in the Brazilian Atlantic Forest.

We tested our hypothesis that assemblages on smooth substrates are a subgroup of the species present on rough substrates with the Nestedness metric based on Overlap and Decreasing Fill (NODF; Almeida-Neto et al. 2008). The metric ranges from 0 to 100 , with $\mathrm{NODF}=100$ representing a perfectly nested assemblage. Our goal was to test the occurrence of a nested pattern in species composition between our treatments, so we calculated the NODF only for rows. We generated 66 presence/absence matrices, 1 for each pair of treatments per block, with the row representing the rough substrate placed above the row representing the smooth substrate. For each of the 66 matrices, we generated 2 null models. The $1^{\text {st }}$ model maintained the number of presences but assigned these anywhere so that neither species nor site total were preserved (rows equiprobable, columns equiprobable). The $2^{\text {nd }}$ model maintained species frequencies, but site frequencies were not preserved (rows equiprobable, columns fixed; Wright et al. 1998, Gotelli 2000, Jonsson 2001). Then, we calculated nestedness for each observed matrix and the equivalent average of 10 random matrices generated by each null model to obtain 2 sets of 66 pairs of nestedness values (the observed value and its respective expected value under each null model). We ran a 1-tailed paired $t$-test for each null model to test whether the observed nestedness was larger than the expected. We conducted all analyses in the $\mathrm{R}$ environment ( $R$ Development Core Team, Vienna, Austria).

\section{Results}

We recorded 92 benthic algal species. Diatoms were the most common and species-rich group, with 56 species and $85 \%$ of the total density in both treatments. The dominant species were the diatoms Achnanthidium minutissimum (Kützing) Czarnecki, Cocconeis placentula Ehrenberg, and Ulnaria ulna (Nitzsch) Compère. 


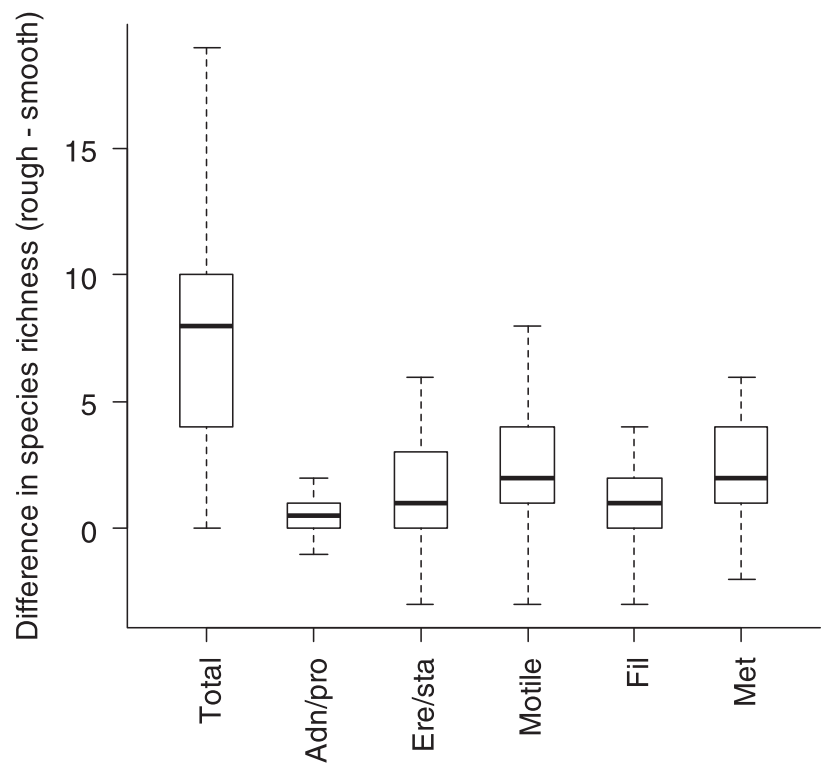

FIG. 1. Box-and-whisker plot of difference in species richness of benthic algae between rough and smooth substrates $\left(\mathrm{S}_{\text {rough }}-\mathrm{S}_{\text {smooth }}\right)$. The experiment was stratified within 66 blocks (i.e., pairs of treatments) tested using a paired $t$-test. Therefore, differences between treatments are presented rather than mean values. The heavy line shows the median, box ends show quartiles, and whiskers show the minimum and maximum. Total $=$ total assemblage, Adn $/$ pro = Adnate $/$ prostrate growth form, Ere $/$ sta = Erect/stalked, Fil $=$ Filamentous, Met $=$ Metaphyton .

Species richness of benthic algae was significantly higher on rough than on smooth substrates $\left(F_{1,64}=\right.$ 199.05, $p<0.001$; Fig. 1), whereas density did not differ between treatments $\left(F_{1,64}=0.72, p=0.439\right.$; Fig. 2). The adnate/prostrate growth form did not differ in richness $\left(F_{1,64}=15.50, p=0.020\right)$ or in density between treatments $\left(F_{1,64}=2.92, p=0.092\right)$, and the erect/stalked growth form showed higher species richness on rough than on smooth substrates $\left(F_{1,64}=38.48, p<0.001\right)$ but did not differ in density $\left(F_{1,64}=2.61, p=0.112\right)$. Motile, filamentous, and metaphytic growth forms were more species-rich $\left(F_{1,64}=52.83, F_{1,64}=33.77, F_{1,64}=127.06\right.$, respectively; all $p<0.001)$ and abundant $\left(F_{1,64}=26.60, F_{1,64}=\right.$ 18.05, $F_{1,64}=48.77$, respectively; all $p<0.001$ ) on rough than on smooth substrates (Figs 1,2).

Substrate roughness affected assemblage composition. Assemblages were significantly different between treatments for both the qualitative Sørensen index $\left(F_{1,130}=8.68, p<0.001\right)$ and the quantitative Bray-Curtis index $\left(F_{1,130}=6.71, p<0.001\right.$; Fig. 3$)$. Furthermore, differences between treatments were not caused by differences in species richness because distinct groups persisted when we used the subsampling procedure (mean $F_{1,130}=4.63$, mean $p<0.001$;

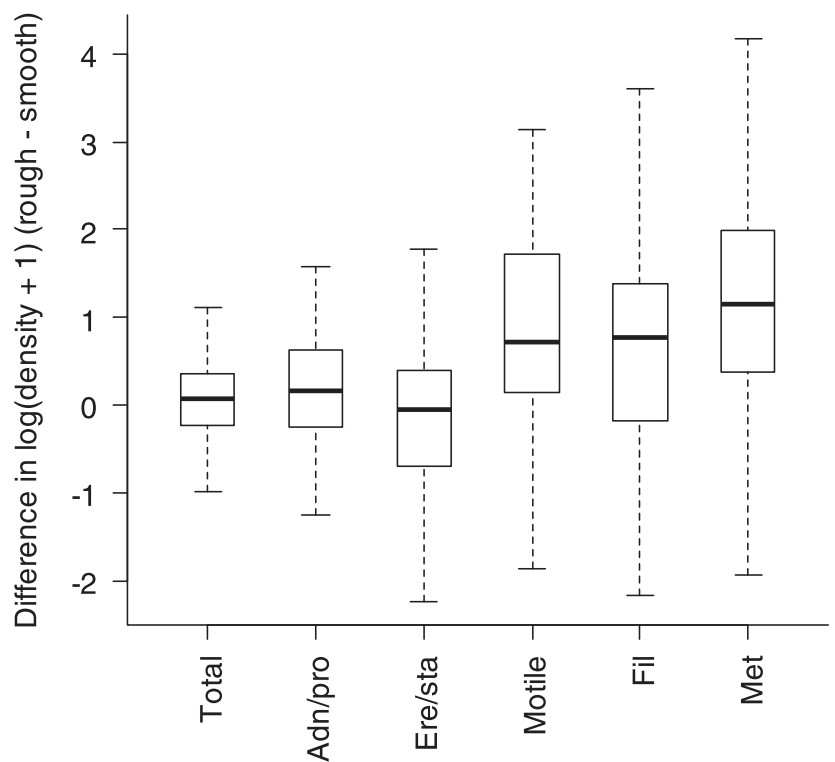

FIG. 2. Box-and-whisker plot of difference in $\log$ (density +1 ) of benthic algae between rough and smooth substrates $\left(\mathrm{N}_{\text {rough }}-\mathrm{N}_{\text {smooth }}\right)$. The experiment was stratified within 66 blocks (i.e., pairs of treatments) tested using a paired $t$-test. Therefore, differences between treatments are presented rather than mean values. The heavy line shows the median, box ends show quartiles, and whiskers show the minimum and maximum. Total $=$ total assemblage, Adn $/$ pro $=$ Adnate/prostrate growth form, Ere/sta = Erect/stalked, Fil $=$ Filamentous, Met $=$ Metaphyton

Fig. 4). The pattern obtained with the PCoA ordination of the subsampled data set (Fig. 4) was similar to that obtained in the ordination of the original qualitative data set, a result indicating that the pattern was not dependent on the number of species. Indicator Species Analysis revealed that only Gomphonema angustatum (Kützing) Rabenhorst was significantly $(p<0.05)$ associated with smooth substrates. On the other hand, 14 species were associated with rough substrates: the stalked species Encyonema minutum (Hilse ex Rabenhorst) Mann in Round et al. (1990), Eunotia incisa Smith, Eunotia praerupta Ehrenberg, and Eunotia faba (Ehrenberg) Grunow; the motile species Navicula cryptocephala Kützing, Surirella tenera Gregory, and Surirella sp. 1; the filamentous species Stigeoclonium sp. and Heteroleibleinia sp.; and the metaphytic species Cosmarium angulosum Brébisson, Cosmarium sp. 2, Cosmarium sp. 3, Closterium incurvum Brébisson, and Staurastrum punctulatum (Brébisson) Ralfs.

Composition of the adnate/prostrate growth-form assemblage did not differ between substrates for either qualitative $\left(F_{1,130}=4.09, p=0.012\right)$ or quantitative $\left(F_{1,130}=2.44, p=0.006\right)$ data sets. On 

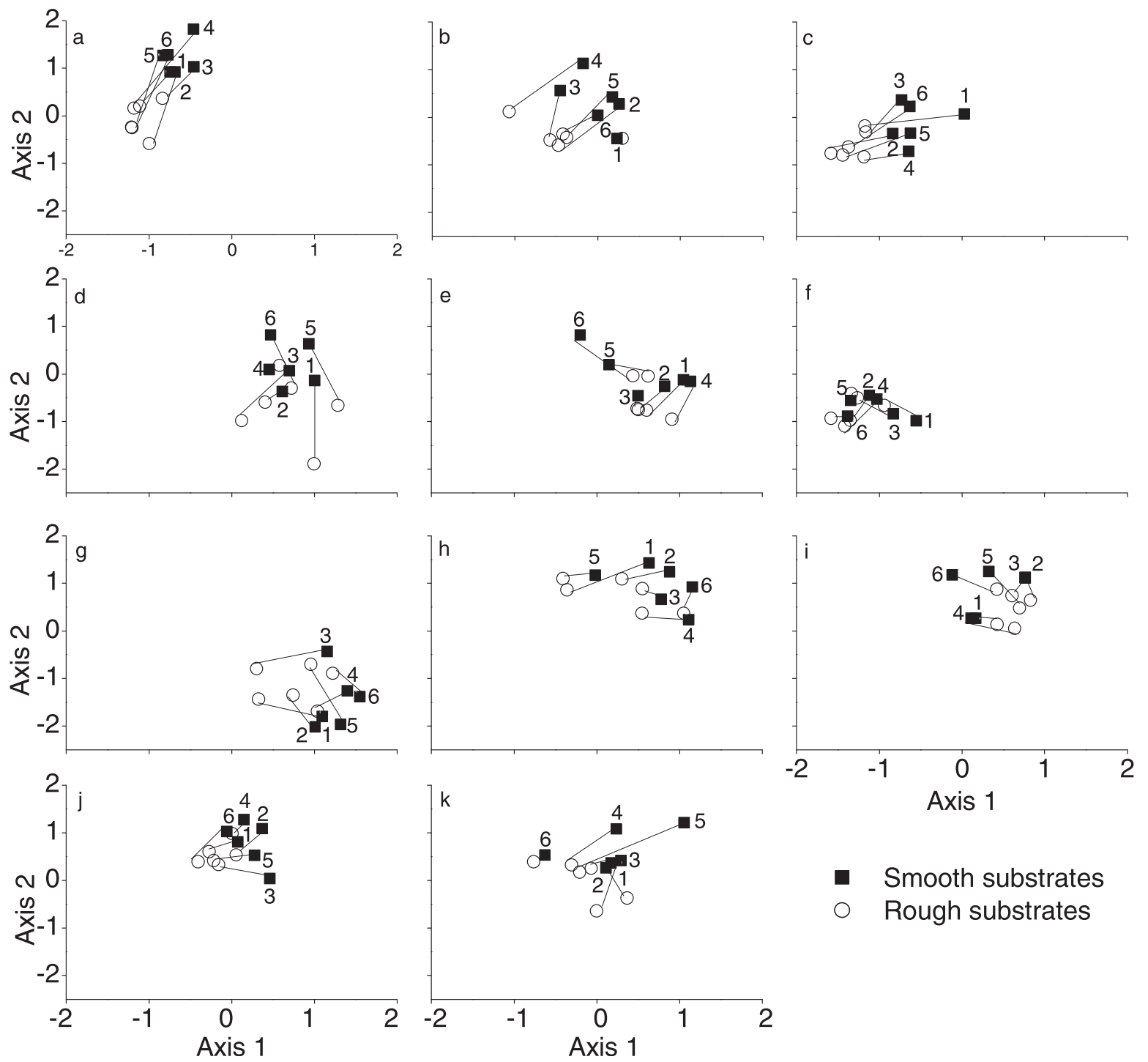

Axis 1

- Smooth substrates
$\circ \quad$ Rough substrates

FIG. 3. Principal Coordinates Analysis (PCoA) plots of benthic algal assemblages on smooth and rough substrates in stream reaches a-k. The analysis was run using the Bray-Curtis index on quantitative data $(\log [\operatorname{density}+1])$. Only 1 PCoA was run, but the axis scores are shown in 11 different plots for clarity (1 plot for each stream reach). Numbers (1-6) indicate the 6 sampling occasions. Lines connect rough and smooth substrates collected on the same sampling occasion.

the other hand, composition differed between substrate types for assemblages of erect/stalked (qualitative: $F_{1,130}=6.61, p<0.001$; quantitative: $F_{1,130}=$ $4.51, p<0.001$ ), motile (qualitative: $F_{1,130}=3.80, p=$ 0.003; quantitative: $\left.F_{1,130}=3.08, p<0.001\right)$, filamentous (qualitative: $F_{1,130}=5.40, p<0.001$; quantitative: $F_{1,130}=5.78, p<0.001$ ), and metaphytic (qualitative: $F_{1,130}=5.28, p<0.001$; quantitative: $F_{1,130}=4.70, p<$ $0.001)$ growth forms.

Benthic algal assemblages had a nested pattern of species distribution (mean nestedness $=73.71$ ). The species on smooth substrates were a subset of the species on rough substrates in analyses with the rows equiprobable/columns equiprobable $\left(F_{1,64}=41.06\right.$, $p<0.001)$ and with the rows equiprobable/columns fixed $\left(F_{1,64}=75.20, p<0.001\right)$ null models.

\section{Discussion}

The occurrence of higher species richness on rough substrates and distinct assemblages between treatments can be attributed to differences in species' natural histories and abilities to deal with different environmental conditions. The adnate/prostrate growth-form assemblage, which had similar species richness, density and assemblage composition between the 2 substrate types, was composed of species that occupy the low strata in the biofilm matrix and are strongly attached, 

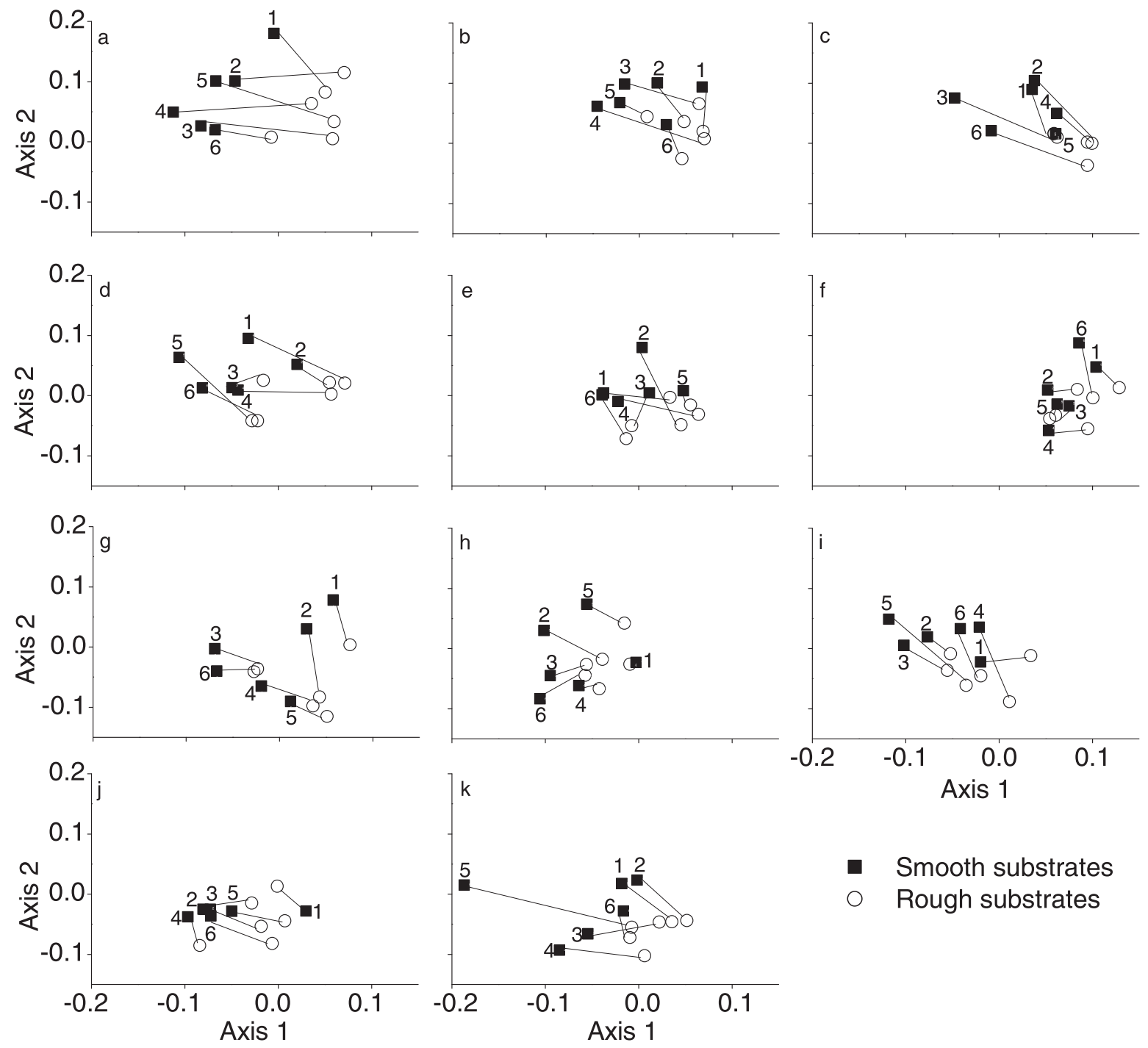

FIg. 4. Principal Coordinates Analysis (PCoA) plots of benthic algal assemblages on smooth and rough substrates in stream reaches a-k. Data were analyzed with the subsampling procedure and the Sørensen index. Symbols indicate averages of 100 ordinations of subsamples containing the same number of species as the experimental unit with the fewest species in the block. Only 1 PCoA was run, but the axis scores are shown in 11 different plots for clarity (1 plot for each stream reach). Numbers (1-6) indicate the 6 sampling occasions. Lines connect rough and smooth substrates collected on the same sampling occasion.

such as A. minutissimum, C. placentula, and Psammothidium subatomoides (Hustedt) Bukhtiyarova and Round. The adnate/prostrate growth form is resource-stressed because it occupies the low strata that may have nutrient and light limitations, but it is resistant to grazing and physical disturbance (Passy 2007), which might enable these algae to occur equally on smooth and rough substrates. Another possible explanation for this result is that adnate and prostrate algae can be dominant on smooth substrates (e.g., Bergey 2005). Our rough substrates had both crevices and smooth surfaces ( $>50 \%$ of the surface of rough substrates), so the similar composition between treatments may have occurred as a result of preferential colonization of smooth substrates.

Metaphytic species (mainly Cosmarium spp., Staurastrum spp., and Closterium spp.) and motile species (e.g., the diatoms Navicula spp. and Surirella spp.) were strongly associated with the rough substrates. These unattached organisms can occur in the mucilage secreted by other algae, lie loose on the sediment, or be freely motile species living on the sediment (Round 1984, Gerrath 2003, Lowe 2003). Rough substrates may accrue a greater biofilm matrix and accumulate more sediment than smooth substrates (Clifford et al. 1992, Bergey 1999), thereby facilitating colonization by 
benthic algae in streams (Wehr and Sheath 2003) and providing additional nutrients to support benthic algal growth (Murdock and Dodds 2007). For example, motile algae can benefit from crevices by using the vertical dimension to exploit available resources and obtain protection from grazers or disturbances (Murdock and Dodds 2007). Authors of some studies have reported higher abundance of filamentous algae on rough substrates than on smooth substrates (Downes et al. 1998, Bergey 1999), and Dudley and D'Antonio (1991) found that zoospores of the filamentous green alga Cladophora glomerata (Linnaeus) Kützing selected crevices for settlement.

Species of the erect/stalked growth form differed in their response to the treatments. For instance, Encyonema minutum, a short-statured stalked species, occurred mainly on rough substrates, whereas Gomphonema species were associated with smooth substrates. Gomphonema is highly tolerant to flow conditions, and most species produce stalks that attach firmly to the substrate (Kociolek and Spaulding 2003). Therefore, they may be able to establish more efficiently than other algal species on smooth substrates.

Our results indicate that both nestedness and turnover affected assemblage composition. The subsampling procedure showed that differences in assemblage composition between treatments were independent of species richness and that assemblages showed species turnover. The nestedness analysis indicated that species in assemblages on smooth substrates were a subset of the species in richer assemblages on rough substrates. Thus, nestedness and turnover are not mutually exclusive, but can occur simultaneously to influence assemblage composition in a manner similar to the simultaneous occurrence of nestedness, checkerboardness, and turnover reported by Heino (2005) for stream midges. Nestedness and turnover can occur simultaneously because species autecological traits and dispersal processes both influence assemblage distribution patterns (Soininen 2008). Some species might depart from the nested pattern (idiosyncratic taxa) by not responding to the main factors that control nestedness (McAbendroth et al. 2005). For instance, Soininen (2008) found that benthic stream diatom assemblages were highly nested, but were characterized by a large number of idiosyncratic species that did not follow the nesting pattern. We suggest that the differences in composition between assemblages on smooth and rough substrates in our experiment resulted from species' different capabilities to establish on substrates with or without crevices, causing both nestedness and species turnover.
Our study provides evidence of the role of substrate roughness in structuring benthic algal assemblages. Substrate roughness strongly affected species richness, assemblage composition, and nestedness. Thus, substrate roughness should be considered in studies of benthic algal assemblages. Further investigations will be necessary to disentangle the possible mechanisms (e.g., occurrence of refuges, sediment deposition patterns) related to fine-scale substrate texture that affect algal assemblage composition.

\section{Acknowledgements}

We thank V. L. Landeiro, S. Larned, and 3 anonymous referees for detailed suggestions that improved our manuscript and Pamela Silver for careful editing of the manuscript. Janet Reid reviewed the English. FS received a student fellowship from the Coordenação de Aperfeiçoamento de Pessoal de Nível Superior (CAPES). ASM received research grants (476304/2007-5; 474560/2009-0) and a research fellowship (302482/2008-3) from the Conselho Nacional de Desenvolvimento Científico e Tecnológico (CNPq).

\section{Literature Cited}

Almeida-Neto, M., P. Guimarães, P. R. Guimarães, R. D. LOYOla, AND W. Ulrich. 2008. A consistent metric for nestedness analysis in ecological systems: reconciling concept and measurement. Oikos 117:1227-1239.

Anderson, M. J. 2001. A new method for non-parametric multivariate analysis of variance. Austral Ecology 26: $32-46$.

BAsElgA, A. 2010. Partitioning the turnover and nestedness components of beta diversity. Global Ecology and Biogeography 19:134-143.

Bergey, E. A. 1999. Crevices as refugia for stream diatoms: effect of crevice size on abraded substrates. Limnology and Oceanography 44:1522-1529.

Bergey, E. A. 2005. How protective are refuges? Quantifying algal protection in rock crevices. Freshwater Biology 50: 1163-1177.

Bergey, E. A., J. T. CoOper, And B. C. Phillips. 2010. Substrate characteristics affect colonization by the bloom-forming diatom Didymosphenia geminata. Aquatic Ecology 44: 33-40.

Biggs, B. J. F., R. J. Stevenson, And R. L. Lowe. 1998. A habitat matrix conceptual model for stream periphyton. Archiv für Hydrobiologie 143:21-56.

Bixby, R. J., J. P. Benstead, M. M. Douglas, and C. M. Pringle. 2009. Relationships of stream algal community structure to catchment deforestation in eastern Madagascar. Journal of the North American Benthological Society 28:466-479.

Buckup, L., A. A. P. Bueno, G. Bond-Buckup, M. Casagrande, AND F. MAjolo. 2007. The benthic macroinvertebrate fauna of highland streams in southern Brazil: composition, 
diversity and structure. Revista Brasileira de Zoologia 24: 294-301.

Burliga, A. L. M., A. Schwarzbold, E. A. Lobo, and V. D. PILLAR. 2004. Functional types in epilithon algae communities of the Maquiné River, Rio Grande do Sul, Brazil. Acta Limnologica Brasiliensia 16:369-380.

Clifford, H. F., R. J. Casey, and K. A. Saffran. 1992. Shortterm colonization of rough and smooth tiles by benthic macroinvertebrates and algae (chlorophyll a) in 2 streams. Journal of the North American Benthological Society 11:304-315.

DARGIE, T. C. D. 1986. Species richness and distortion in reciprocal averaging and detrended correspondence analysis. Vegetatio 65:95-98.

Downes, B. J., P. S. LaKe, E. S. G. Schreiber, and A. Glaister. 1998. Habitat structure and regulation of local species diversity in a stony, upland stream. Ecological Monographs 68:237-257.

Downes, B. J., P. S. LaKe, E. S. G. Schreiber, and A. Glaister. 2000. Habitat structure, resources and diversity: the separate effects of surface roughness and macroalgae on stream invertebrates. Oecologia (Berlin) 123:569-581.

Dudley, T. L., And C. M. D'Antonio. 1991. The effects of substrate texture, grazing, and disturbance on macroalgal establishment in streams. Ecology 72:297-309.

DufrÊNE, M., AND P. LegENDRE. 1997. Species assemblages and indicator species: the need for a flexible asymmetrical approach. Ecological Monographs 67:345-366.

Ferro, V. G., AND A. S. Melo. 2011. Diversity of tiger moths in a Neotropical hotspot: determinants of species composition and identification of biogeographic units. Journal of Insect Conservation (in press). doi: 10.1007/ s10841-010-9363-6

Gerrath, J. F. 2003. Conjugating green algae and desmids. Pages 353-381 in J. D. Wehr and R. G. Sheath (editors). Freshwater algae of North America: ecology and classification. Elsevier, San Diego, California.

GotelLi, N. J. 2000. Null model analysis of species cooccurrence patterns. Ecology 81:2606-2621.

Heino, J. 2005. Metacommunity patterns of highly diverse stream midges: gradients, chequerboards, and nestedness, or is there only randomness? Ecological Entomology 30:590-599.

Hutchens, J. J., J. B. Wallace, and E. D. Romaniszyn. 2004. Role of Podostemum ceratophyllum Michx. in structuring benthic macroinvertebrate assemblages in a southern Appalachian river. Journal of the North American Benthological Society 23:713-727.

JONSSON, B. G. 2001. A null model for randomization tests of nestedness in species assemblages. Oecologia (Berlin) 127:309-313.

Kociolek, J. P., And S. A. Spaulding. 2003. Eunotioid and asymmetrical naviculoid diatoms. Pages 655-668 in J. D. Wehr and R. G. Sheath (editors). Freshwater algae of North America: ecology and classification. Elsevier, San Diego, California.

Lange, K., A. Liess, J. J. Piggott, C. R. Townsend, and C. D. MAtTHAEI. 2011. Light, nutrients and grazing interact to determine stream diatom community composition and functional group structure. Freshwater Biology 56: 264-278.

Legendre, P., And L. Legendre. 1998. Numerical ecology. Elsevier, Amsterdam, The Netherlands.

Lennon, J. J., P. KolefF, J. J. D. GReEnWoOd, AND K. J. Gaston. 2001. The geographical structure of British bird distributions: diversity, spatial turnover and scale. Journal of Animal Ecology 70:966-979.

LowE, R. L. 2003. Keeled and canalled raphid diatoms. Pages 669-684 in J. D. Wehr and R. G. Sheath (editors). Freshwater algae of North America: ecology and classification. Elsevier, San Diego, California.

Lowe, R. L., S. W. Golladay, and J. R. Webster. 1986. Periphyton response to nutrient manipulation in streams draining clearcut and forested watersheds. Journal of the North American Benthological Society 5:221-229.

LowE, R. L., AND G. D. LALiBERTE. 2007. Benthic stream algae: distribution and structure. Pages 327-356 in F. R. Hauer and G. A. Lamberti (editors). Methods in stream ecology. Elsevier, London, UK.

McAbendroth, L., A. Foggo, S. D. Rundle, and D. T. Bilton. 2005. Unravelling nestedness and spatial pattern in pond assemblages. Journal of Animal Ecology 74:41-49.

Murdock, J. N., AND W. K. DodDs. 2007. Linking benthic algal biomass to stream substratum topography. Journal of Phycology 43:449-460.

Palmer, M. A., H. L. Menninger, and E. Bernhardt. 2010. River restoration, habitat heterogeneity and biodiversity: a failure of theory or practice? Freshwater Biology 55: 205-222.

PAssY, S. I. 2007. Diatom ecological guilds display distinct and predictable behavior along nutrient and disturbance gradients in running waters. Aquatic Botany 86:171-178.

Round, F. E. 1984. The ecology of algae. Cambridge University Press, Cambridge, UK.

Round, F. E., R. M. Crawford, and D. G. Mann. 1990. The diatoms: biology and morphology of the genera. Cambridge University Press, Cambridge, UK.

SoININEN, J. 2008. The ecological characteristics of idiosyncratic and nested diatoms. Protist 159:65-72.

TANiguchi, H., AND M. TOKeSHI. 2004. Effects of habitat complexity on benthic assemblages in a variable environment. Freshwater Biology 49:1164-1178.

Vieira, L. C. G., L. M. BinI, L. F. M. Velho, and G. R. MazÃo. 2007. Influence of spatial complexity on the density and diversity of periphytic rotifers, microcrustaceans and testate amoebae. Fundamental and Applied Limnology Archiv für Hydrobiologie 170:77-85.

Wehr, J. D., And R. G. Sheath. 2003. Freshwater habitat of algae. Pages 11-57 in J. D. Wehr and R. G. Sheath (editors). Freshwater algae of North America: ecology and classification. Elsevier, San Diego, California.

Wright, D. H., B. D. Patterson, G. M. Mikkelson, A. Cutler, AND W. Atmar. 1998. A comparative analysis of nested subset patterns of species composition. Oecologia (Berlin) 113:1-20.

Received: 7 April 2011

Accepted: 8 August 2011 